\title{
BİR HÂFIZ DÎVÂNI ŞERHLERİ DERLEMESİ: ZÂHİD BİN MUHAMMED VE ESERI
}

\author{
Esma Şahin* \\ Mustafa Turan**
}

$\ddot{\mathbf{O z}}$

Osmanlı şerh geleneğinde en rağbet gören eserlerden biri şüphesiz Hâfız-1 Şîrâzî (ö.792/1390[?])'nin Dîvân'ıdır. Osmanlı şairlerinin büyük bir hayranlıkla takip ettikleri ve gerek Osmanlı gerek İran topraklarında tarih boyunca beğeniyle okunan bu usta şairin şiirleri yüzyıllarca şerhler yapılmak suretiyle anlaşılmaya/anlatılmaya çalışılmıştır. Hâfız'ın şiirlerine yapılan meşhur tam şerhler Sürûrî (ö.969/1561-62), Şem ‘î (ö.1011/1602-1603) ve Sûdî (ö.1007/1599) ile 19. yüzyılda Konevî (ö.1244/1828-29)'ye aittir. Bu şerhler dışında farklı yüzyıllarda Hâfız'ın şiirlerine yapılan tercümeler ve kısmî şerhler de mevcuttur. Şerh literatürü içinde birden fazla eserden derlenen bölümlerin bir arada şerh edildiği eserlerle sıkça karşılaşılırken aynı esere yapılmış iki farklı şerhin bir araya getirildiği örneklere pek rastlanmaz. Bu anlamda özgün olarak değerlendirilebilecek eserlerden biri yine Hâfız Dîvânı için ortaya konmuştur. Dîvân'a Surûrî ve Şem ‘î tarafından yapılan şerhlerin bir araya getirilip derlendiği bu eser 16. yüzyıl sonlarında (1005/1597) Zâhid bin Muhammed tarafından kaleme alınmıştır. Eserin bilinen tek nüshası Süleymaniye Kütüphanesi Nuruosmaniye 3962 numarada kayıtlıdır. Bu makalede Zâhid bin Muhammed ve eseri tanıtılmaya çalışılmıştır.

Anahtar Kelimeler: Hâfız-1 Şirâzî, dîvân, şiir, şerh, Şem ‘î, Sürûrî

\section{A COMPILATION OF THE COMMENTARIES ON THE DIVAN OF HAFEZ: ZAHID BIN MUHAMMED AND HIS WORK}

\section{Abstract}

One of the most popular works in Ottoman commentary tradition is undoubtedly the Divan of Hafez-i Shirazi. The poetry of this master poet who followed with great admiration by the Ottoman poets and whose divan was constantly read by the people of Ottoman and Iranian lands had been tried to be explained in many commentarial works

Article Types/Makale Türü: Research Article/Araştırma Makalesi

Received/ Makale Geliş Tarihi: 02.11.2019, Accepted / Kabul Tarihi:11.12.2019

Doi: $10.26791 /$ sarkiat.641874

* Dr.Öğr.Üyesi, İstanbul Medeniyet Üniversitesi, Edebiyat Fakültesi, Türk Dili ve Edebiyatı Bölümü

ORCID ID: https://orcid.org/0000-0003-1720-6542

** Mardin Artuklu Üniversitesi Yüksek Lisans Öğrencisi

ORCID ID: https://orcid.org/0000-0001-8127-6962 
through centuries. The famous full commentaries made for Hafez's poems belong to Surûrî (d.969/1561-62), Şem‘î (d.1011/1602-1603), Sûdî (d.1007/1599) in the $16^{\text {th }}$ century and Konevi (d.1244/1828-29) in the 19 $9^{\text {th }}$ century. Apart from these commentaries, there are translations and partial annotations made to the poems of Hafez in different centuries. In the commentary literature, it is commonly encountered with the works where the chapters compiled from more than one work are annotated together and there are not many examples where two different annotations made in the same work are brought together. In this sense, one of the works that can be considered as original had been put forward for the Divan of Hafez. This work, in which the commentaries made by Surûrî and Şem'î for the Divan were brought together and compiled, was written by Zahid bin Muhammad at the end of the $16^{\text {th }}$ century $(1005 / 1597)$. The only known manuscript copy of the work is registered at Nuruosmaniye 3962. In this article, Zahid bin Muhammad and his work have been tried to be introduced.

Keywords: Hafez-i Shirazi, divan, poetry, commentary, Shem`i, Sururi

\section{GíRiş}

Fars şiirinin önde gelen şairlerinden olan ve Şiraz'da doğup hayatını orada sürdürdüğü için "Şîrâzî" nisbesiyle anılan Hâce Şemseddin Muhammed Hâfız-1 Şirâzî (ö. 792/1390[?])' nin hayatı hakkındaki bilgiler sınırlıdır. Hâfız'ın büyük âlimlerin kitaplarını okuduğu ve "Hâce" unvanını kullandığına bakılırsa iyi bir eğitim aldığı ve seçkin bir aileye mensup olduğu anlaşılmaktadır. Dinî ilimlerin yanı sıra Arap Edebiyatı başta olmak üzere iyi bir şiir kültürü de edinmiş olan şair, eğitimi sırasında Kur’ân-1 Kerîm'i ezberlediği için kendisine "Hâfız" denilmiştir. Bu lakabın, onun güzel bir sese sahip olması ve gazel okumasından kaynaklanmış olabileceği (Safâ, 2005: 184) görüşü de bulunmaktadır. Erken yaşlarda şiirleriyle tanınmaya başlayan Hâfız'ın henüz hayattayken şöhreti Hindistan'dan Bengal'e kadar ulaşmıştır. Şiirlerinin, ölümünden sonra Muhammed Gülendam adlı biri tarafından toplandığı görüşü, kendisi hayattayken bir araya getirildiği anlaşılan bazı divan nüshalarının tespit edilmesiyle ortadan kalkmıştır (Yazıcı, 1997: 103-106). Dîvân nüshalarındaki farklılıklar sebebiyle şiirlerinin sayısı net değildir. Kendisine aidiyeti şüpheli olan pek çok şiir de bulunmaktadır. Bununla birlikte Gölpınarlı neşrinde (1992) 499 gazel, 1 terkib-i bend, 1 terci-i bend, 1 Sâkî-nâme, 1 mesnevî, 36 kıta, 42 rubâ‘̂̂, 3 müfred ve 2 muamma yer alır. Hâfız’a ait olduğu şüpheli 80 gazel, 1 muhammes, 14 kıta, 5 kaside ve 26 rubâ‘̂îye de bu çalışmada yer verilmiştir ${ }^{1}$.

Farklı nazım şekillerinde şiirler yazmış olan Hâfız asıl şöhretini gazellerine borçludur. $\mathrm{O}$, kendisine gelinceye kadar tek konusu aşk olan gazeli, her bir beyti bağımsız bir form olarak ele alıp içerik bakımından zenginleştirmiştir (Hürremşâhî, 1280: 32-33; Ayar, 2013: 289-290). Hâcû-yı Kirmânî, Kemâleddîn-i Isfahânî, Mevlânâ ve Sâ'dî-i Şirâzî gibi isimlerden etkilenen Hâfız, Osmanlı şairlerinden Ahmed Paşa, Şeyhî, Fuzûlî, Bâkî, Nef'î, Nedim ve Şeyh Galib gibi pek çoğunu etkilemiş, Bâkî onun üç şiirini tahmis etmiştir. Diğer yandan Hâfız Dîvânı Osmanlı' da yüzyıllar boyu Mevlânâ'nın Mesnevî̀ si başta olmak üzere Sa'dî'nin Bostân ve Gülistân'1 gibi eserlerle birlikte en çok okunan kitaplardan biri olmuş, bilhassa Farsça öğretmek, şiir tekniği ve estetiği hakkında bilgi

1 Hâfız'ın bazı gazellerine şerh tekniği bakımından Sûdî ve Konevî'nin yaklaşımları üzerine hazırlanan bir tez çalışmasında dîvândaki şiir sayısı 66 rubâ‘̂̂, 1 Sâkî-nâme, 1 Mugannî-nâme, 5 kaside, 1 muhammes, 4 mesnevi, 34 kıta ve 509 gazel olarak belirtilmiştir (Ayar, 2007: 5). 
edindirmek için okutulmanın yanında Osmanlı şerhlerine kaynaklık eden önemli metinler arasına da girmiştir. Şiirlerindeki semboller ve tasavvufî derinlikten dolayı “tercümânü'l-esrâr" ve "lisânü'l-gayb" olarak anılan Hâfız'ın şerh kültüründeki yeri daha çok şiirlerindeki kapalılık, anlam derinliği ve sembolik dilden kaynaklanır. Şerhlerin dibacelerinde de kaydedildiği üzere şârihler onun dîvânını tasavvufi remizlerle dolu şiirlerinin daha iyi anlaşılabilmesi için şerh etmeye çalışmışlardır.

Hâfız Dîvânı'nı Osmanlı sahasında ilk şerh eden kişi Sürûrî (ö.969/1561-62)'dir. Sürûrî'den sonra Şem‘î (ö.1011/1602-3[?]) 981/1574 yılında bir şerh kaleme almıştır. 16. yüzyılda Şem ‘î’yi Sûdî (ö.1007/1599[?])'nin şerhi takip eder. 19. yüzyılda ise Mehmed Vehbî b. Hasan el-Konevî (ö.1244/1828) Hâfız'ı şerh etmiştir. Bu şerhlerin hepsi tam şerhlerdir. Sûdî dışındakiler tasavvufî yaklaşımlarla şerhlerini kaleme almışken Sûdî’nin şerhi metnin kültürel çağrışımlarına, somut yönüne ve gramer açıklamalarına ağırlık verilerek yapılan bir şerhtir. Sûdî metnin tasavvufî yönünü de göz ardı etmez ancak eksik bulduğu gerçekçi yönünü tamamlamaya çalışır (Arı, 2016: 102103). Bu bakımdan onun şerhi dil ve kültür tarihi açısından da önem taşır. Sûdî aynı zamanda Sürûrî ve Şem ‘î’’nin şerhlerindeki hatalara ve yorumlarında onlara katılmadığ noktalara dikkat çekerek eleştirel özellik taşıyan bir şerh ortaya koymuştur. 16. yüzyılda Hüseyin İbrahim el-Kefevî'nin de bir Hâfız Dîvânı şerhinden söz edilmektedir. Ancak bu şerh henüz ele geçmemiştir (Yazar, 2011: 494). Şerhler dışında Hâfız Dîvânı'nın tercümelerinin de yapıldığ görülür. Mustafa Tevfik (1661'den sonra)'in dîvânın "ayn" harfine kadar yapmış olduğu tercüme bunlardan biridir. 18. yüzyılda Ferîdî (ö.1799'dan sonra) adlı bir şair Hâfız Dîvânı'nı manzum olarak tercüme etmiştir ${ }^{2}$. Ayrıca mütercimi belli olmayan ve Hâfız' ın seçilmiş bazı gazellerinin kelime kelime tercüme edildiği bir eser Millet Kütüphanesi Edebiyat 203 numarada kayıtlıdır (Yazar, 2011: 496). Hâfız Dîvânı'ndan yalnızca bazı gazel ve beyitler üzerine kısmî şerhler de yapılmıştır³.

Sürûrî ve Şem ‘̂̂’ nin Hafız şerhleri bir mukaddime ile başlar. Sürûrî, mukaddimesinde eskilerden bazı hâl sahiplerinin tarikat ahvâli ve hakikat sırlarını remiz ve ima yoluyla, kapalı sözlerle gizli şekilde anlattıklarını, "tercümânü'l-esrâr" ve "lisânü'l-gayb” olarak nitelendirilen Hâfız'ın da şiirlerinde remiz ve kapalılığı seçtiğini, tasavvuf yolundan ve tarikat sırlarından habersiz olanların bunları anlamadıklarını ve bazılarının ise hayrette kaldıklarını belirtir. Gönül ehli ve ârif bazı kimselerin kendisinden bu sırları Türkçe olarak açıklamasını istediklerini, kendisinin de bilip anladığı kadarıyla mecazî ve hakikî manaları özetle açıklamaya çalıştı̆̆ını söyler. Böylece anlayışı eksik olanların kâmil olması, gafil kimselerin ise gönül ehli olmalarına vesile olmak umulur. (Nuruosmaniye 3962: vr.1b; Oğuz, 1998: 37-38). Anlaşıldığ1 üzere burada eserin telif edilme sebebi Hâfız'ın şiirlerinde anlamın kendini kolay ele vermemesi ve okuyanlara anlama yolunda rehberlik etme isteğidir.

Sürûrî, dîvânı şerh ederken diğer manzum şerhlerinde de olduğu gibi birim olarak mısraı esas almış ve her mısraın önce tercümesini, sonra şerhini vermiştir. Şiirlere daha çok tasavvufî açıdan yaklaşmış, kelimeleri açıklarken çoğu kez asıl anlamlarından

2 Eser üzerine bir doktora çalışması yapılmıştır (Emrullah Yakut, Ferîdî̀nin Manzum Hâfız Dîvânı Tercümesi (Ínceleme - Metin), Yayınlanmamış Doktora Tezi, İstanbul Üniversitesi, 2015).

3 Bunlardan biri Cevrî'nin Hâfız Dîvânı'ndaki ilk gazele yapmış olduğu şerhtir. Bu şerh makale olarak yayınlanmıştır (Turgay Şafak, "Cevrî Çelebi’ye Nispet Edilen Hâfız-1 Şîrâzî Gazeli Şerhi”, Mukaddime, 6: 51-69, 2012). Bir diğeri Derviş Abdülkâdir'in Hâfız'ın bir gazeli için kaleme aldığı Galebe-i Sultân-ı Aşk isimli bir şerhtir. Eser yüksek lisans tezi olarak çalışılmıştır (İbrahim Kolunsağ, Derviş Hâfız Abdülkadir Galebe-i Sultân-ı Aşk (Metin-İnceleme), Yayınlanmamış Yüksek Lisans Tezi, İstanbul: Kültür Üniversitesi, 2012). Bu şerhlerle ilgili ayrıntılı bilgi için ayrıca şu çalışmalara bakılabilir: Yazar, 2011; Ar1, 2016. 
uzaklaşmıştır (Oğuz, 1998: 25). Sonraki yıllarda Hâfız şiirlerinin lafzî manalarına ağırlık vererek şerh eden Sûdî, onun bu yanlışlarını kendi şerhinde eleştirmiştir. Mısraların önce tercümesini veren Sürûrî bazen kısa gramer bilgileri verdikten sonra "ma'nâ-yı mısra' budur ki" diyerek misraın tercümesine geçmiş ve tercümeyi Farsça söz dizimini bozmadan gerçekleştirmiştir. Bu nedenle cümleler devriktir. Misraın tercümesinden sonra tasavvufi açıdan şerh etmiştir. (Oğuz, 1998: 25). Öte yandan Sürûrî ilk gazellerde mısraların her birinin önce tercümesini, sonra şerhini verirken sonraki gazellerde mısraların tercümesini ayrı ayrı verdikten sonra iki mısraın şerhini birlikte vermiş, şerh kısmında beyti bütün olarak ele almıştır. Zaman zaman gramer açıklamalarına da yer veren Sürûrî’nin gramere yönelik açıklamaları ilk gazellerde daha yoğundur. Sonraki gazellerde yer yer kısa gramer bilgileri vermiş veya yalnızca tercüme ve şerh ile yetinmiştir. Şerhlerinde sık sık âyet, hadis, kelâm-1 kibar gibi iktibasların yanı sıra Mevlânâ, Sa 'dî, Attâr, Câmî gibi şairlerden gazel, rubâ‘î, beyit ve kıt'alara tasavvufî̀ yorumlarını desteklemek üzere yer vermiştir. Bununla birlikte şerhler arasında görüşlerini destekleyici ve açıklayıcı hikâyeler de bulunur. Sürûrî Şem ‘î’ye kıyasla şerhlerinde bu tür örnek ve şahitlere daha fazla yer vermiştir. Sürûrî'nin şerhinin derkenarlarında ise bazı kelime ve kavramların anlamları, gramer bilgileri, nüsha farkları ve gazellerin vezinleri bulunur. Sürûrî Hâfız'ın rubâ‘î, kıt'a ve gazellerini şerh etmiş; kaside, mesnevi, sâkî-nâme ve muganni-nâme türündeki diğer şiirlerini şerh etmemiştir.

Şerhine Farsça bir mukaddime ile başlayan Şem ‘î, mukaddimesinde Hâfız'ın şiirleri ile ilgili tasavvufi bir imada bulunmamış, yalnızca Ahmed adlı birisinin 1srarı neticesinde şerhi yazmaya başladığını söylemiştir (Ayasofya 4062: 1b; Nuruosmaniye 3962: 2a; Arı, 2016: 95). Şem ‘î’ nin şerhi de Sürûrî’ nin şerhindeki gibi birim olarak mısra esasına dayanır. Mısralar kurallı bir biçimde tercüme edildikten sonra tasavvufî bakış açısıyla şerh edilir. Tasavvufî anlamlar genellikle misralarda yer alan kelimelerden bazen de mısraın bütününden çıkarılır. Bazı mısraların şerhinde kısa gramer tahlilleri yapıldığı da görülür. Zaman zaman beyit alıntılarına yer verilir. Şem ‘î’nin şerhi mısraların genişletilmiş tercümeye yaklaşan bir yöntemle kısaca şerh edildiği bir eserdir (Yazar, 2011: 493). Şerhinde genel olarak Sürûrî’yi takip eden Şem ‘̂̂’nin beyit tercümelerinde Sürûrî'ye göre daha fazla Arapça ve Farsça kelime kullandığı görülür. Genel manada gramer açıklamalarına ve tafsîlî şerhe pek girmeyen Şem 'î, ilk seksen varaktan sonra aynı şeyleri tekrar etmemek için icmâlî şerhe geçtiğini, ıstılahlar arasında her zaman bağlantı kurmayacağını da belirtir ${ }^{4}$. Şem ‘î, açıklamalarında yer yer Sürûrî’den istifade etmiştir (Arı, 2016: 98). Şem 'î’ nin şerhinin derkenarlarında kısa gramer bilgileri, kelime anlamları ve beyitlerde geçen kelime/kavramların tasavvufî açılımları bulunur.

Sürûrî ve Şem ‘î tafsilatlı açıklamadan ziyade genişletilmiş tercüme şeklinde (Yazar, 2011: 45) bir şerh usulü takip etmişlerdir. Onların metotlarındaki benzerlik tasavvufî yorum ve yaklaşımlarında da kendini gösterir. Aslında her iki şerh birbirini tamamlayan

4 Ma lūm ola ki şimden sonra icmāl üzre şerhe şurūe olınur. Murād beyān olınan ıșṭlāḥı tekrār '1yān eylemek ma kūl degüldür. Zīiā 1ṭnāba sebeb olur. Pīr-i mugāandan murād mürşid ve meyden murād '1ş̣ ve ḩam-1 ebrūdan murād gaybet-i hüviyyet ve zülüfden murād gāh zulmet-i kevn ve gāh esrār-1 ilāhiyye ve ḥālden murād noḳṭa-i zâat ve ṣabādan murād feyz-i ilāhī ve bunlardan gayrı nice 1ṣtılāḥāt beyān olınmışdur. Bāḳīsini bunlara kıyās ideler ve bacżı maḥalde yine işāret iderüz. Ba żı maḥalde terkīb ma nāsına ta`arruż itmezüz, belki ma nā-yı muḥașṣalası üzre şerh iderüz. Bunuy gibileri ḩaṭā ile zannetmeyeler. Eger 'ārifī yek işāret besest (Ĕğer ârif isen bir işâret yeter)" (Ayasofya 4062: 84b-85a; Ar1, 2016: 98). 
özelliktedir. Sonradan kaleme aldığı şerhinde Şem‘î, Sürûrî’nin şerhini tasdik edip referans almış, yalnızca bazı durumlarda farklı noktalara dikkat çekmiştir. Arı'ya göre bu iki şerhteki benzerlik aynı yüzyılın sonlarında Zâhid bin Muhammed adlı bir mürettibin dîvâna yapılmış bu iki şerhi bir araya getirerek ortak bir metin oluşturmasına sebep olmuştur. (2016: 99). Şerh literatüründe Arapça, Farsça veya her iki dilde, birden fazla eserden bölümlerin bir araya getirilerek tercüme/şerh edildiği eserler mevcuttur ${ }^{5}$. Ancak aynı esere yapılmış olan iki ayrı şerhi bir araya getiren derleme örneğine rastlanmamıştır. Dolayısıyla Zâhid bin Muhammed'in Hâfız Dîvânı için yapmış olduğu derleme bu anlamda tek örnek gibi görünmekte ve eserin önemini artırmaktadır. Aşağıda eserin nüshası, mürettibi ve tertip metodu ile ilgili bilgi verilecektir.

\section{Nüsha Tavsifi}

Şem ‘î ve Sürûrî’nin Hâfız Dîvânı şerhlerinin derlendiği eserin el yazması nüshası Süleymaniye Kütüphanesi Nuruosmaniye 3962 numarada kayıtlıdır. 388 varak olan bu nüsha 295x200-210x135 mm ebadındadır. Cildi kırmızı derili, oval şemseli, köşebentli ve mıkleplidir. Miklebinde de şemse vardır. Hasar görmüş ve ek yerlerinden kopmuş olan cildin üzerinde kurt yenikleri bulunur. Varaklar 33 satırdır ve reddadelidir. Bazı varaklarda satır sayısının 34 olduğu da görülür. Kaba nesihle yazılmıştır. Derkenarda notlar ve açıklamalar bulunur. $1 \mathrm{~b}$ ve $2 \mathrm{a}$ dışında yazının etrafında cetvel görülmez. Yazım esnasında metin içine sığmayan bazı kelime ve eklerin satır dışına yazıldığı görülür. Yazmada ilk varaklarda yeni bir gazele geçişte kullanılan "velehû eyzan" ibaresinin yazılacağı yerler 10b'den itibaren muhtemelen sonradan yazılmak üzere boş bırakılmıştır. "Velehû eyzan" ve "beyt", "gazel", "rubâ‘̂̂̀", "kıt'a" gibi şiir alıntıları ile gazellerde yeni bir harfe geçişi gösteren "hurûfu'l-bâ", "hurûfu'z-zâ" vb. ibareler ilk varaklarda kırmızı mürekkeple yazılmıştır. Kırmızı mürekkep kullanımı ilk varaklar haricinde son birkaç varakta da görülmekle birlikte geri kalan varaklarda -yeni bir harfe geçişi gösteren ibareler dışında- kullanılmamıştır. Esasen nüshanın genelinde kırmızı mürekkep kullanımında belli bir düzen olduğu da söylenemez.

Ahmet Ateş nüshanın Zâhid bin Muhammed'in kendi el yazısıyla yazdığı nüsha olduğunu belirtir ${ }^{6}$ (Ateş, 1968: 302). Nüshada üzeri çizilmiş/karalanmış pek çok kelime/cümle ve derkenarlarında çok sayıda düzeltme ve notun bulunması da bunun bir işareti sayılabilir. Esere sonradan eklenmiş olduğu anlaşılan "Kitâb-1 Şem'î ve Sürûrî "Alâ Dîvân-1 Hâfız" ismi el yazmasının etek kısmında yer alır. Vikaye sayfasında ise ince bir yazıyla yine "Şem î̀ ve Sürûrî 'Alâ Dîvân-1 Hâfız" yazar. Zahriye sayfasında iki mühür bulunur. Sayfanın üst orta kısmında yer alan büyük mühür III. Osman'a aittir. Mühürde 'Elhamdülillâhi'llezî hedânâ li-hâzâ vemâ künnâ li-nehtediye lev lâ en hedâna'llâh" " ayeti yazılıdır. Mührün hemen altında noktasız talik yazıyla el yazmasının III. Osman'ın vakfettiği bir eser olduğuna dair bir kayıt bulunur. Bu kaydın altında evkaf memuruna ait bir mühür vardır ve üzerinde "bende-i latîf İbrâhîm Hanîf" yazar. Zahriye sayfasındaki III. Osman'a ait mührün bir benzeri silik ve okunaksız bir şekilde 2a' da derkenarda bulunur.

5 Örnekler için bkz. Yazar, 2011: 235.

6 I. Mahmud tarafından kurulan ve çok değerli bir koleksiyona sahip Nuruosmaniye Kütüphanesinin III. Osman tarafından sahiplenilerek kendisine mal edilmesi serüvenini anlatan Esad Serezli, kütüphanenin çok sayıda süslü ve tezhipli nüshanın yanında müellif hattı ile yazılan ve başka hiçbir yerde nüshası olmayan nadir eserler bulundurduğuna dikkat çeker (1948: 19-20).

7 "Bizi buna ulaştıran Allah'a hamdolsun. Eğer Allah bize hidayet etmeseydi biz kendiliğimizden bu hidayete erişemezdik." (Araf, 43) 
El yazması 1b varağında eserin mürettibi Zâhid bin Muhammed'in kendi mukaddimesi ile başlar; hemen ardından Sürûrî ve Şem ‘î’nin şerhlerine ait mukaddimeler peş peşe gelir. 2a'nın ortalarından itibaren ise gazel şerhlerine geçilir ve 384a'ya kadar bu şekilde devam eder. 384 . varakta Sürûrî'nin şerhinin bittiği ters üçgen şekli verilmiş:

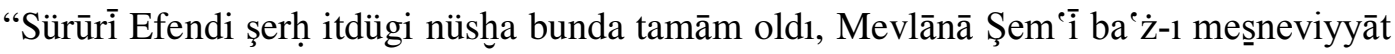
ve ba ¿̇-ı kasīde ve sāḳī-nāme ve mugannī-nāme diyü dahı şerh itse gerekdür, temmet.”

sözleriyle ifade edilir ve buradan itibaren Şem ‘î’nin şerhettiği diğer şiirlerle eser devam eder. Eserin sonunda ferağ kaydı bulunur.

Baş: Raḥmet ol mü’min ḳarındaşumuza ki bu kitābı yazdı̣̣da bunı daḩı bilece yaza: Aṣhāāb-1 'uşşāḳ ve zümre-i pür-eşvāḳ (...)

Son: Kad ferag̉a min tenmīḳi hāža'l-kitābi el-faḳir Zāhid bin Muhammed gafera'llāhu lehu ve li-vālideyhi ve ahseni ileyhümā ve ileyhi fī evāsıṭi Şa bāni'l- 'aẓim min şuhūri hamse ve elf.

Ferağ kaydına göre eser h.1005/m.1597 Şaban ortalarında (Mart/Nisan) yazılmıştır. Ferağ kaydından sonra yazarın okuyanlardan fatiha dileğinde bulunduğu Türkçe ve Farsça beyitler yer alır.

Nüshada yanlış noktalanmış veya noktası konulmamış harflere rastlanır. Örneğin hānḳāh kelimesi metnin pek çok yerinde noktasız yazılmıştır ( 211b/21). Bazen metinde unutularak yazılmamış harf veya ekler bulunduğu da görülmüştür (سعت رحمثلك/ه)

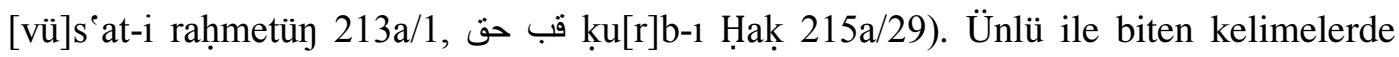

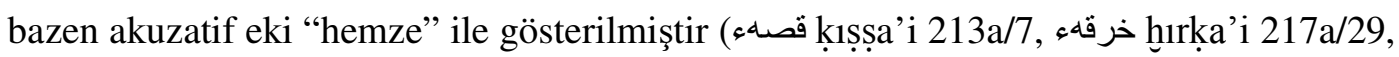
كمساءء kimse'i 213b/9). Hemze ile yazılan bazı kelimelerde hemze yerine "y" kullanıldı̆̆ görülür (دايم dāyim 221a/22, زايل zāyil 207b/29, فايده fāyide 205/12). Aleyhi's-selâm ibaresi "ayn" ve "mim" (عم) ile gösterilmiştir.

\section{Zâhid bin Muhammed}

Hâfız Dîvânı' na Şem 'î ve Sürûrî tarafından yapılan şerhleri bir araya getiren Zâhid bin Muhammed hakkında yalnızca eserinden yola çıkarak bazı bilgiler edinebiliyoruz. Kendisinden "İpekli gâzîlerin şehlevendi" olarak bahseden Zâhid bin Muhammed, bu ifadeden anlaşıldığı üzere İpek şehrindendir. Bugünkü Kosova sınırları içinde yer alan bir şehir olan İpek (Peja / Peć) 1455'te Fatih Sultan Mehmed'in Sirbistan'1 ele geçirmesiyle Osmanlı topraklarına katılmıştır. 1479'da İşkodra Venedikliler'den alınınca yeni kurulan İşkodra sancağına İpek de dâhil edilmiş, 1530'dan sonra ismini eski bir Arnavut asilzade ailesi Dukaginler'den alan Dukagin sancağının kurulmasıyla sancağın önemli bir kasabası olmuş ve Dukagin sancak beylerinin ikametgâhı hâline gelmiştir (Kiel, 2000: 366-368). Osmanlı'da pek çok şair, yazar ve aydın kimsenin yetiştiği Balkanlar bölgesinden olan Zâhid Efendi yine eserinin mukaddimesindeki "Essâkin fî mahmiyye-i İpek" ifadesinden anlaşıldığı kadarıyla eserini de İpek'te iken kaleme almıştır. Zâhid bin Muhammed bir müellif olmaktan ziyade Sürûrî ve Şem 'î tarafından Hâfız Dîvânı'na yazılmış şerhleri bir araya getirip düzenleyen bir mürettiptir. Nitekim eserinde o da kendisinden mürettip olarak söz eder: 
“El-mürettibü'l-faḳiir Zāhid bin Muḥammed ‘afã ‘anhüma’r-Rabbu’ṣ-Ṣamed, es-sākin fî̀ maḥmiyye-i İpek." (1b)

Mürettibi bunun Zāhid Efendi

İpekli gāāīlerün şeh-levendi

Kazā çevgānınuy ya nī esīri

Fakỉri müstemendi derdmendi (388b)

İpekli olduğu ve eserini orada kaleme aldığı anlaşılan Zâhid bin Muhammed'in kendisini "gâẑ̂" ve "şeh-levend" olarak tanımlamasına bakılırsa Osmanlı döneminde öncü ve komutan olarak fetihlere katılmış ve askerlik görevinde bulunmuş olduğu düşünülebilir. Doğum ve ölüm tarihleri bilinmediği için yaşadığı dönem yine eserini yazdığı tarihten yola çıkarak anlaşılabilmektedir. Eserin kaleme alınış tarihi 1005 (1597)'tir. Buna bağlı olarak kendisinin 16. yüzyılın ikinci yarısında yaşadığı, eserini hayatının son dönemlerinde yazmadıysa 16.yy. sonları ile 17. yy. başlarını/ilk yarısını idrak ettiği söylenebilir. Zâhid bin Muhammed mukaddimesinde eserine herhangi bir isim verdiğinden söz etmez. Ancak el yazmasının etek kısmında sonradan eklendiği anlaşılan "Kitâb-1 Şem ‘î ve Sürûrî 'Alâ Dîvân-1 Hâfız" ismi dikkat çeker.

\section{Kitâb-ı Şem'î ve Sürûrî 'Alâ Dîvân-ı Hâfız ve Tertip Metodu}

Kitâb-ı Şem'î ve Sürûrî 'Alâ Dîvân-ı Hâfız, Hâfız'ın şiirlerine 16. yüzyılın meşhur şârihlerinden Şem ‘î ve Sürûrî’nin yapmış olduğu şerhlerin bir araya getirilip derlendiği bir eserdir. Eserin bilinen tek nüshası Süleymaniye Kütüphanesi Nuruosmaniye 3962 numarada kayıtlıdır. Bu eserden ilk olarak Ahmet Ateş İstanbul Kütüphanelerinde Farsça Manzum Eserler I adlı çalışmasında söz eder (1968: 302). Ahmet Atillâ Şentürk ve Ahmet Kartal'ın hazırladığı Eski Türk Edebiyatı Tarihi (2005: 343)'nde de Ahmet Ateş'in eserinden faydalanılarak böyle bir eserin varlığından bahsedilmiştir. Osman Sacid Arı "Mehmed Vehbi Konevî’nin Hafız Şerhi'nde Tasavvufî Unsurlar" (2016: 99) başlıklı tez çalışmasında yine Ahmed Ateş'ten alıntı yaparak Zâhid bin Muhammed ve eserinden söz etmiştir. Zâhid bin Muhammed'in mukaddimesine de yer veren Arı, Hâfız'ı tasavvufî zeminde anlayan bu iki şerhin bir araya getirilerek ortak bir metin oluşturulmasını bu eserlerin aynı geleneği takip ettiği ve birbirini tamamladığına dair toplumsal kabulün bir işareti sayar. Şem ‘î’nin, şerhinde Sürûrî’yi her anlamda dikkate aldığı ve referans kabul ettiğini de ekleyen Arı, bunu her iki metinden verdiği örneklerle gösterir. Tercüme, şerh üslubu ve tasavvufi yorumlardaki yakınlıkların bu iki eserin birbirini takip eden eserler olduğunu ve Hâfız'1 anlamada belirleyici rol oynadığını, bununla da kalmayarak Konevî’nin şerhine kaynaklık ettiklerini belirtir (2016: 100102).

Zâhid bin Muhammed'in aynı çizgide kaleme alınmış bu iki eserdeki yorumları bir araya getiren bir eser ortaya koymaktaki temel amacı, eseri okuyanların Sürûrî ve Şem ‘̂̂ şerhlerini bir arada bulabilme ve kolayca okuyabilmeleridir. Şüphesiz böylece Hâfız'ın daha iyi anlaşılmasına katkıda bulunacağı gibi iki şerhin kıyaslanmasına da imkân sağlayacaktır. Mukaddimesinde belirttiği üzere âşıklar zümresi olarak nitelendirdiği tasavvuf büyükleri, tarikat hâlleri ve hakikat sırlarını ima ve remizler yoluyla tasavvuf yoluna yeni girenlere anlatmışlar; "tercümânü'l-esrâr" olan Hâfız da şiirlerinde 
mecazlar yoluyla bunlara işaret etmiştir. Fakat anlayışı eksik olan bazı kimseler bu sırları idrak edemeyip hayrette kalmışlardır. Zâhid bin Muhammed'in ifadelerine göre Sürûrî aslında Hâfız'ın şiirlerini dervişane ve sülûk hâllerine uygun bir şekilde şerh etmiş, bazı kimseler bununla yetinmeyip Şem ‘î’nin de bir şerh yazmasını istemişler, ısrarlara dayanamayan Şem ‘î bir şerh kaleme almış ve eserinde Sürûrî’nin verdiği bazı manaları beğenmeyip bazısını açıkça bazısını üstü kapalı reddetmiştir. Şem‘î ve Sürûrî'nin, şerhlerini nasıl ve ne amaçla kaleme aldıklarını kısaca özetleyerek konuyu kendi eserine ve eserini kaleme alma sebebine getiren Zâhid bin Muhammed, gönlüne bu iki değerli kişinin şerhlerini bir araya getirme fikri ve heyecanının düştüğünü, bu bahaneyle de insanlar tarafından hayırla yâd edilmek istediğini ifade eder. Mukaddimesinin hemen öncesinde "Rahmet ol mü'min k̦arındaşumuza ki bu kitâbı yazdıkda bunı dahı bilece yaza" diyerek bu mukaddimenin sonraki zamanlarda müstensihler tarafından eserin başına eklenmesi isteğini hasseten dile getirir. Eserin derlenme sebebini anlatan satırlarla birlikte mukaddime kısmı aşağıdadır:

“Aṣhāb-1 uşşāḳ ve zümre-i pür-eşvāḳ 'ale'l-ittifāḳ cemì 'i māsivādan ictināb ve iftirāk üzre olup dünyā-yı denīnüy sürūrı ḳayd u bendiyle mukayyed olmayup pīrezen-i dehre zebūn olmag̀1 ihtiyār itmeyüp ḳuyūd-1 dünyeviyye'i '1şḳ āteşine iḥrāḳ ve ‘ale'l-1ṭlāḳ dünyānuy cāhını çāh ve dirhemini hem ve dīnārını nār ve devletini let ve 'izzetini zillet ve ni'metini mihnet bilüp rāḥatını zaḥmetine degmez diyü ' $1 y s ̧ ~ u$ 'işret-i hakịikīye müştāḳ ve devām-1 üns-i Haḳk’a iştiyāḳ üzre olup aḥvāl-i țariḳati ve esrār-1 ḥaḳiḳati remz ve ỉmā ile ehl-i sülūke beyān itmişlerdür. Meşhūr-1 āfāk ve ḩavāṣṣ-1 'uşşāḳdan olan Şemseddīn Muhammedü’l-Ḥāfızu'ş-Şirāzī -ki laḳabları tercemānü’l-esrārdurḳaddese'llāhu sırrahu'l-'azīz daḩı naẓm ü eşeārla ve șūret-i mecāzī țariḳıyle işeār itmegi iȟtiyār idüp anlar daḩı '1yān itmişlerdür. Lākin fehminde ḳuṣūrı olan ehl-i sülūkden ba '̇̇ idrāk idimeyüp mütehạayirlerdür. Merhūmun cemī ${ }^{e}-i$ eşeārınuy ma nā-yı mecāzì ve ma nā-yı haḳi kịisini merḥūm Sürūrī Efendi dervişāane ta bīir ve aḥvāl-i sülūke mülāyim tefsīr idüp şerḥ itmiş iken ba żż-1 aṣhāb-1 devlet bunuyla ḳanāeat itmeyüp Dīvān-ı Hāfız’un tekrār şerh olınmasına țālib olup Mevlānā Şem î̀'ye ilḥạ̣̄-ı bisyār idüp Mevlānā-yı mezbūr dah̆ı 'acz ü ḳuṣūrına mu'terif olup hezār i'tizār ve 'adem-i iḳtidārla cevāb virüp mücāb olmayıcaḳ nāçār ibrām-1 bī-şümārdan șoyra "fa'tebirū yā üli'l-ebșāar"8 muḳteżāsınca anlar daḩı şerh itmişler, lākin Sürūrī Efendi virdügi ba żı maenālarını begenmeyüp kimini tasrịhen ve kimini ta 'rīzen redd itmişdür. Bināen 'alā żālik bu faḳī țaraf-1 hayra sālik olup hāṭ̂r-1 fātıruma bu halecān itdi ki bu iki 'azizüy şerḥlerini bir yire

8 “Ey basiret sahipleri! İbret alın!" (Haşr, 2) 
cem idüp derc ü īrād ve bu bahāne ile yād olınam. İmdi evvelā Sürūrī

Efendinüy şerḥ ü beyān itdügi ‘alā vechi’t-telhīs yazılup andan sonra Mevlānā Şem ‘ī şerḥ ü '1yān itdügi 'alā vechi't-ta ḳ̣īb yazılup tertīb olındı, gaflet olınmaya." (1b)

Yukarıdaki satırlardan anlaşıldığı üzere Zâhid Efendi eserini nasıl tertip ettiğinden de yine mukaddimede bahsetmiştir. Buna göre mürettip, önce özetle Sürûrî’nin şerh ettiği kısımları, akabinde Şem ‘î’nin şerh ve açıklamalarını yazmıştır.

Mukaddimesinin devamında Zâhid bin Muhammed "Bütün mü'minler kardeştir" hadis-i şerifi gereğince gönül ehli seçkin kişiler ve kalp sahibi ârif kimselerden zengin-fakir, âmir-memur bu iki şerhe bakıp feyz alarak istifade eden herhangi bir mümin kimsenin bu şerhleri bir araya getiren kardeşlerinin âkıbetinin hayır olması için bir fatiha okumalarını temenni eder. Bütün mümin kardeşlerinin de âkıbetlerinin hayır olmasını Allah'tan dileyerek mukaddimedeki sözlerini bitirir:

"ve "küllü mü’minün 1ḩvetün"9 muḳteżāsınca ehl-i dilden ẓurefā ve erbāb-1 ḳulūbdan 'urefā eger ganī vü fakịir ve eger 'abīd ü emīir her ḳanġı mü'min ḳarındaşumuz bu iki şerhe naẓar idüp ikisinden daḩı ifāża ve istifāża ve ifāde ve istifāde ide, ümīddür ki hulḳ-1 kerīmlerinden ve luṭf-1 'amīmlerinden bu iki şerḥi bu üslūb üzre mürettib olan ḳarındaşlarınuy hātime-i ḩayr olmag içün fătiḥa oḳıyalar ve ol hażret-i bìi-niyāza niyāzumuz budur ki cemī'-i mü'min ḳarındaşlarumuzun 'āḳıbetleri hayr ola. Āmīn yā Rabbe'l- ēàlemīn bihürmeti men hüve seyyidi'l-mürselīn.” (1b)

Müellif, fatiha isteğini eserinin sonunda yazmış olduğu Türkçe ve Farsça beyitlerde de dile getirmiştir. Aynı zamanda bu eser vesilesiyle Allah'ın rahmet, lütuf ve ihsanına nail olma isteğinde de bulunduğu görülür:

Anuyçün çekmişem bu dẹlü zaḥmet

Dilerem kim yazana Ḥaḳ ide rạ̣met

İki şerh buldı bu tertīb üzre itmām

Mürettib olana dị Hạ ide in ām (388b)

“Bütün mü’ minler kardeştir.” (Hadis) 
Bunı yazdum yādigār olmagi içün

Yazıcıya bir du’ā ḳılmag içün

Her ki hāned hatṭ̂-1 men ümmīd mīdārem ez ān

Ez berā-yı rūḥ-1 men yek fātiḥa ḩāned revān ${ }^{10}(388 b)$

Zâhid bin Muhammed mukaddimesinin sonunda ismini zikrederken yine İpek şehrinden olduğunu belirten tanıtıcı şu ifadelere yer vermiştir:

“El-mürettibü'l-faḳiì Zāhid bin Muḥammed 'afã ‘anhüma'r-Rabbu'ṣ-Ṣamed, es-sākin fî̀ maḥmiyye-i İpek, ḥumiyet min şerr-i mā halak, Ḩālıḳu'l-ins ve’l-melek.” (1b)

Eserin başındaki kendi mukaddimesinden sonra Zâhid bin Muhammed bir araya getirdiği iki şerhin mukaddimelerine yer vermiştir. Kendi mukaddimesinde de Sürûrî ve Şem ‘î’nin eserlerini telif etme sebeplerini onların mukaddimelerinden özetle anlatarak söze başladığı ve ardından kendisinin bu eseri derleme sebebini dile getirdiği görülür. Mürettibin mukaddimesinde kullandığı ifadeler Sürûrî'nin mukaddimesinde yer alan ifadelere oldukça benzer niteliktedir:

Sürûrî:Aṣ̣āb-1 ḥālden- selef-i șālihịin -rıżvānu'llāhi te ālā 'aleyhim ecma īn- ạ̣vāl-i țarīkati ve esrār-1 ḥaḳiḳati remz ü ỉmā ve ta 'miye vü ihfā țarịịiyle beyān itmişlerdür (...) ve bu zümrenüy içinde lisānü'lgayb ve tercemānü'l-esrār laḳab virilen Şemseddīn Muhammedü'lḤāfiẓu'ş-Şirāzī ḳaddese'llāhu sırrahu'l- 'azīz cemīe-i eş ārında remz ü elḡāzda ve șūret-i mecāzda ibrāz țarīḳini ihtiyār idüp tā aḥvāl-i sülūkde gāâil ve esrār-1 țarịkatden zāhil olanlar ḳuṣūr-1 fehminden inkār-1 küllì ḳılup ve ba żı̇ mütehayyyir ḳalup (...) (Nuruosmaniye 3963: 1b)

Zâhid bin Muhammed: "Așhāāb-1 uşşāḳ ve zümre-i pür-eşvāḳ (...) aḥvāl-i țarịkati ve esrār-1 hakịiḳati remz ve ìmā ile ehl-i sülūke beyān itmişlerdür. Meşhūr-1 āfāk ve ḩavāṣṣ-1 'uşşāḳdan olan Şemseddīn Muhammedü'l-Ḥāfı̣u'ş-Şirāzī -ki laḳabları tercemānü'l-esrārdurḳaddese'llāhu sırrahu'l- 'azīz daḩı naẓm ü eşeārla ve șūret-i mecāzī țariḳıyle işeār itmegi iḩtiyār idüp anlar daḩı '1yān itmişlerdür. Lākin

10 Yazdığımı okuyan her kimseden ruhuma bir fatiha okumasını ümit ederim. 
fehminde ḳuṣūrı olan ehl-i sülūkden ba '̇̇̇ idrāk idimeyüp mütehayyyirlerdür. (Nuruosmaniye 3962: 1b)

Sürûrî'nin dibacesine yer vermeden önce Zâhid Efendi "kâle Mevlânâ Sürûrî fi'ddîbâce" ve "Bismi'llâhi'r-Rahmâni'r-Rahîm ve bihî nesta'în" diyerek dibaceyi aynen alıntılamıştır. Hemen ardından "kâle Mevlânâ Şem 'î fi'd-dîbâce” diyerek Şem 'î'nin Farsça dibacesine yer verir. Dibacelerden sonra "harfü'l-Elif" ara başlığıyla gazel şerhlerine geçilir.

Zâhid bin Muhammed Şem ‘î ve Sürûrî’nin mısra birimini esas aldıkları şerhlerini beyit birimini esas alacak şekilde bir araya getirmiş ve birleştirmiştir. Mürettip Hâfız'ın beytini bir bütün olarak yazdıktan sora önce Sürûrî'nin tercümesini iki mısraın tercümesini birleştirecek şekilde vermiş, sonra Sürûrî'nin mısralara dair şerhlerini önce birinci mısra, sonra ikinci mısra olmak üzere ardı ardına yerleştirmiştir. Ancak akışa göre bazen ikinci mısrain şerhini öne aldığg da görülür. Bu durum Şem‘î’nin şerh tertibinde de aynı şekilde devam ettirilir. "Mevlânâ Şem ‘î dir" ifadesinden sonra Şem ‘î'nin misra tercümeleri birleştirilerek verilir ve şârihin çoğu kez "murâd" veya "murâd budur ki", bazen de tasavvufî anlamlara işaretle "ma'nâ-yı tasavvufîsi budur", "ma'nâ-yı tasavvufîsi üzere" (203b/32) kalıplarıyla verdiği şerh, tercümeyi takip eder. Burada şârihlerin ilk beyitlerde mısraları ayrı ayrı tercüme ve şerh ettiklerini, belli bir yerden sonra ise misraları ayrı ayrı tercüme ettikten sonra her iki mısraın şerhini bir arada verdiklerini söylemek gerekmektedir. Dolayısıyla Zâhid bin Muhammed de beyit tercümelerini birleştirmesinin ardından şerh metinlerinde olduğu şekliyle şerhlere bütün hâlinde yer vermiştir. Mürettip her beyit için tercüme ve murad edilen mana ve tasavvufî anlamları derli toplu bir biçimde metnine aldıktan sonra şerhlerde verilen diğer bilgi ve şahitler konusunda belli bir yöntem takip etmez.

Zâhid bin Muhammed beyitlerden sonra "Mevlânâ Sürûrî dimiş" ifade kalıbıyla Sürûrî'nin tercüme ve şerhini ard arda verirken "Mevlânâ Şem ‘î dir" kalıbıyla Şem ‘̂̂'nin tercüme ve şerhine geçer. Mürettip 55b'ye kadar düzenli olarak Hâfız'ın beytinden hemen sonra Sürûrî'nin şerhini vereceğine işaret etmek üzere "Mevlânâ Sürûrî dimiş" kalıbını kullanmış; sonrasında ise bu kalıbı çoğu kez kullanmadan doğrudan şerhe -okuyucunun ilk şerhin Sürûrî’ye ait olduğunu anlayacağını düşünerekgeçmiştir. Ancak "Mevlânâ Şem‘î dir" kalıbı, iki şerhin ayrımını göstermesi bakımından aksatmadan metin boyunca tekrar edilmiştir. Bu söz kalıplarında Sürûrî için duyulan geçmiş zaman (dimiş), Şem ‘î için ise geniş zaman (dir) kipinin kullanılması dikkat çekicidir. Bu ifade tarzı Sürûrî’nin (ö.969/1562) eserin yazıldığı tarihte (1005/1597) ölmüş olmasıyla, Şem‘î’nin (ö.1011/1602-1603 [?]) ise henüz hayatta bulunmasıyla ilgili olmalıdır.

Mürettibin iki ayrı eseri bir arada vermeye çalışırken kullanılması zorunlu bazı bağlayıcı ifadeler veya mısra birimine dayalı şerh metodundan beyit birimine dayalı bir derlemeye geçişte zorunlu olan bazı düzenleme ve ifade değişiklikleri dışında ${ }^{11}$ genel olarak şerhlere kendisinden bir şey katmadığı ve cümleleri aynen alıntıladığı

11 Örneğin Sürûrî "Mīkoned Ḥāfıẓ du āyē bişnev āminī begū" mısraından hemen sonra "Ḥarf-i ye (ى) iki yirde vaḥdet içündür" (Nuruosmaniye 3963: 3b/23) diyerek misraın tercümesini verir. Zâhid bin Muhammed ise beyit düzeniyle gittiği için beytin ardından bir bütün hâlinde tercüme ve beyitten murad edileni verdikten sonra "Āminì ve du’āyî̀'de olan [ye (ى)] vaḥdet içündür" (4a/24) şeklinde açıklamayı kendi metnine uyarlar. 
söylenebilir. Ancak bazen cümlelerde bazı Arapça, Farsça kavramları Türkçeleştirdiği veya bazı ibareleri anlatımı uzatmamak için almadığı, mukaddimesinde de belirttiği gibi "özetle" alıntıladığı görülür ${ }^{12}$. Ayrıca kimi zaman şârihlerin gramere dair bazı açıklamalarını atladığı, yalnızca tercüme ve anlama dair şerhlerine yer verdiği yahut bazı kelime anlamlarını almadığı görülür. Gramer açıklamaları daha ziyade ilk gazellerde olduğu için sonraki gazellerde açıklamalar yalnızca tercüme ile birlikte kısa şerh veya genişletilmiş tercüme şekline dönüştüğünden tabiî olarak kısaltma ihtiyacı duymaz ve birebir alıntılar. Gramer açıklamalarının mısra tercümesinden önce verildiği bazı durumlarda (Nuruosmaniye 3963, 7a/16) ise mürettip tercümeyi öne alarak gramer bilgisini tercümenin hemen ardından ve şerhten önce vermiştir (8b/20).

Şerhlerde açıklamalar içinde şahit getirilen kısmî veya tam ayet ve hadis iktibasları, Arapça atasözü, deyim, kelâm-1 kibâr ve Câmî, Sa'dî, Attâr gibi şairlerden verilen şiir örnekleri ile anlatımı güçlendirici kıssa ve hikâyeler bulunur. Ayet, hadis, atasözü, deyim gibi Arapça ibareler genellikle alınırken hikâye ve bir gazelin tamamı gibi uzun şiir alıntılarının kimi zaman alınmakla birlikte çoğu kez alınmadığı görülür. Bir beytin şerhi yalnızca Sürûrî'nin şerhinde yer alıyorsa "Bu beyt Şem ‘î şerh itdügi nüshada bulınmadı", "Bu beyt Şem‘î şerh itdügi dîvânda bulınmadı" veya "Bu beyt dahı Şem ‘î' de bulınmadı” gibi cümlelerle o beytin şerhinin Şem ‘î’nin eserinde yer almadığı belirtilir. $\mathrm{Bu}$ ifade kimi zaman metin içine yazılmayı unutulduğunda derkenara yazılmıştır (206b).

Şerhlerde beyitlerde kastedilen asıl mananın veya bir kavramın beyitte kastedilen manasının verildiği kısımlarda kullanılan "murâd" "...-dan murâd" veya "murâd budur ki", "hâsıl-1 ma'nâ" gibi klişe kalıplar, alıntılanan şerhlerde olduğu gibi korunmuştur. Ancak Sürûrî'nin kısa gramer bilgisi ve bir açıklama verip mısraın tercümesine geçtiği zaman kullandığı "ma'nâ-yı mısra budur ki" kalıbı yerine "ma'nâ-yı beyt budur ki" kalıbı kullanılır (215b/22). Sürûrî’nin beyitlerdeki Farsça söz dizimini bozmadan yapmış olduğu tercümeler bu eserde de aynen alıntılandığı için özellikle beyitlerin ilk (Sürûri’ye ait) tercümelerinde cümleler devriktir. Sürûrî ve Şem ‘î’nin tercümelerinin bazı kelime farkları dışında aynı olması metnin tekrarlarla dolu olduğu izlenimine sebep olmaktadır. Özellikle tercüme haricinde fazla açıklama yapılmadan bırakılan beyitlerin şerhinde her iki şârihin tercümelerinin ard arda gelmesi bunu daha fazla hissettirir.

Eserde gazellerin vezni gösterilirken Sürûrî’nin şerhinde uyguladığı yöntem takip edilmiş ve gazel başlangıçlarında derkenara her bir gazelin vezni yazılmıştır. Hâfız'ın beyitleri belirginleştirilmek için üst tarafına çizgi çizilmiştir. Şem ‘î’nin şerhine geçildiğini gösteren kalıp ifadenin de üzerine çizgi çekildiği görülür. $\mathrm{Bu}$ yöntem şerhlerde şahit getirilen nazım parçalarını gösteren beyit, rubâ'î, kıt' a gibi sözcüklere de uygulanir.

Yazmanın derkenarlarında açıklayıcı notlar, kelime anlamı ve beyitlerle ilgili kısa gramer bilgileri yer alır. Zâhid bin Muhammed Şem'î ve Sürûrî şerhlerinde derkenarlarda bulunan notların hepsini almamakla birlikte kendi metninde de yine bu notlara derkenarlarda yer vermiştir. Ancak zaman zaman şerhlerdeki derkenar notlarının bazen ana metnin içine alınarak verildiği veya şerhte ana metin içinde olan bir notun

12 Burada Zâhid bin Muhammed'in Sürûrî ve Şem‘î şerhlerinin hangi nüshasını kullandığı bilinmediğinden/elde olmadığından bu gibi tasarruflardan bazılarının nüsha farkı olabileceği de göz ardı edilmemelidir. 
derkenara alındığı da görülebiliri ${ }^{13}$. Derkenarlarda özellikle gramer bilgisi içeren kısa notlar kimi zaman esere alınmamıştır. Mürettip derkenardaki kelime anlamı, açıklama ve notların kime ait olduğunu "Monlâ Sürûrî", "Monlâ Şem '̂̀” diyerek belirtmiştirr".

Mürettip derlediği şerhler bağlamında Hâfız'ın beyitlerine ait nüsha farklarını da derkenarlarda göstermiştir. Bu farklar tek bir kelime farkından ibaretse mısra içinde o kelimenin hemen altında (203b/17) gösterilmiş, mısraın bütününde farklılık mevcutsa mısra tümüyle derkenara yazılmıştır. Bu farklar Şem ‘î’nin şerhinde esas aldığı nüshadaki farklılıklardır. Dolayısıyla mürettibin Sürûrî’nin şerhindeki metni esas aldığı söylenebilir. Derkenara yazılan mısra farklarında farkın Şem ‘î'nin esas aldığı metne ait olduğunu göstermek üzere misrain yanına/altına "Şem ‘î", "Monlâ Şem‘î", "İhtâr-1 Şem 'î" gibi ibareler yazılmıştır. Bu ibarelerle birlikte bazı nüsha farklarının yanında (نخ) kısaltması da görülür ${ }^{15}$. Şârihlerin kendi metinleri içinde belirttikleri bazı nüsha farklılıkları da vardır. Daha çok Sürûrî’nin metninde geçen bu farklara Zâhid bin Muhammed de söz konusu şerh metinlerinde olduğu gibi "Ba'z-1 nüsahda böyle vâki" olmışdur” diyerek yer vermiştir (204a/8). Sürûrî’nin derkenarlarda vermiş olduğu nüsha farkları da bulunur. Bunlar Zâhid bin Muhammed'in metninde yer almaz ${ }^{16}$.

Derkenarda şerhlerdeki notların haricinde Zâhid bin Muhammed'in düzeltme/eklemeleri bulunur. Mürettip metin içine yazmayı unuttuğu/atladığı bir kelime, söz öbeği veya cümleyi ok işaretiyle satır arasındaki yerini belirterek derkenara yine aynı ok işareti ve "sahh" notuyla kaydetmiştir (179b, 329a, 333b). Metin içinde yanlış yazdığı kelime veya cümlelerin üzerini çizmiş/karalamıştır (202b/12, 216/3).

Sürûrî iki mısraın birbirine anlamca bağlı olduğu beyitlerde açıklamasını yaptıktan sonra "Bu beyt merhûndur" notuna yer verir. Kimi zaman ise iki mısra arasına "merhûndur" ibaresini koyarak tercümelerini misraları birleştirerek (beyit hâlinde) yaptığı görülür (Nuruosmaniye 3963: 4b/2; Çelik, 1996: 15-16). Zâhid bin Muhammed derlemesini beyit birimi üzerine tesis ettiğinden her iki durumda da Sürûrî'nin tercüme ve şerhinden sonra "Bu beyt merhûndur" açıklamasını yapar (217a/25, 219b/7).

\section{4. Örnekler}

1. Aşağıdaki örnek beyit şerhinde Şem ‘î ve Sürûrî’nin mısra birimini esas alarak kaleme aldıkları şerhlerinin Zâhid bin Muhammed tarafından beyit birimine dayandırılarak

13 Bu durumda yine Zâhid bin Muhammed'in kullandığı Sürûrî ve Şem‘î nüshalarını göz önünde bulundurmak gerektiği hatırlanmalıdır. Bu nedenle bu hususta kesin bir yargıya varmak mümkün değildir.

14 Bazı derkenarlarda yalnızca "Monlâ" ibaresinin olduğu, muhtemelen unutularak notun kime ait olduğunun yazılmadığı görülmektedir. Nitekim 213b derkenarda bulunan “e Arbede gavàgā dimekdür" notu Şem ‘î’ nin şerhinde (Ayasofya 4062: 177a) derkenarda bulunur. Aynı şekilde "ḩod-bīn vașf-1 terkībīdür” (210b) şeklindeki not da yine Şem ‘̂̂’nin şerhinde (Ayasofya 4062: 174b) yer alır. 2a'daki "Bunda zikr itdügümüz tafșīl kütüb-i tefāsīrde șūre-i Baḳara evvellerinde "Yā eyyühe'n-nāsü budū Rabbeküm” āyetinde meşrūḥ ve mübeyyendür" notu ise Sürûrî’nin şerhinde (Nuruosmaniye 3963: 2a) derkenarda bulunur.

15 Sürûrî’nin nüsha farklarını çoğu kez metin içinde "Ba'zı nüsahda böyle vâki 'olmışdur” diyerek veya derkenarda "نخ”" kısaltmasıyla verdiği belirtilir (Çelik, 1996: 40). Zâhid bin Muhammed aynı kısaltmayı zaman zaman kullanmakla birlikte derkenarlarda yalnızca Şem‘î’nin şerhte kullandığı nüsha farklarını vermiştir.

16 Örneğin Sürûrî, Nuruosmaniye 3963: 195b derkenarda yer alan nüsha farkı ile ilgili bir not Zâhid bin Muhammed' in eserinde aynı beytin şerhinin bulunduğu 205b'de yoktur. 
düzenlenmiş bir örneği görülebilirr ${ }^{17}$. Zâhid bin Muhammed bu beytin şerhinde herhangi bir eksiltme yoluna gitmeden her iki şârihin metnini alıntılamıştır. Metinlerde görülen ufak tefek kelime ve ifade farklarının Zâhid bin Muhammed'in tasarrufu olma ihtimali yanında nüsha farkından kaynaklanmış olabileceği de göz önünde bulundurulmalıdır. Beyit için Sürûrî' de yer alan derkenar notu Zâhid bin Muhammed'in metnine de alınmıştır.

Zâhid bin Muhammed (205b/3-8)

$$
\begin{aligned}
& \text { Men ez nesīm-i sühan-çin }{ }^{18} \text { çe taref ber-bendem } \\
& \text { Çü serv-i rāst der in bāg nīst mahrem-i rāz }
\end{aligned}
$$

Ben ḳovıcı nesīmden ne gūşe bag̉layam ve rāḥat olam dog̉ru serv gibi bu bāğda yoḳdur mạ̣rem-i rāz. Murād hevāyī olanlara keşf-i rāz itmeyüp müstaḳīm olanları hem-rāz idinmege irşāaddur. Mevlānā Şem ì dir, ben gammāz nesīmden ne ümīd bag̉layam ve ne fā'ide hạậ̣l idem müstaḳim serv gibi bu bāg̉da maḥrem-i rāz degüldür. Bu hem vech-i laṭiffür, çünki rāst serv bu bāg̉da maḥrem-i rāz degüldür. Murād ṣuleḥā rāz-1 '1şḳa mạ̣rem degül, ḳande ḳaldı ki 'avām rāz-1 ' 1 ş̣̣a maḥrem ola dimekdür. Vech-i evvele göre murād herkes maḥrem-i rāz olmag̉a lā’iḳ degüldür dimekdür.

Sürûrî (195b/16-19)

$$
\text { Men ez nesīm-i sühan-çin }{ }^{19} \text { çe taref ber-bendem }
$$

Ben ḳovıcı nesīmden ne gūşe bag̉layam ve rāḥat olam.

\section{Çün serv-i rāst nīst der īn bāg mahrem-i rāz}

Ṭoğru serv gibi yoḳdur bu bāg̉da maḥrem-i rāz. Murād hevāyī olan kimse keşf-i rāz itmeyüp müstakịm olanları hem-rāz idinmege irşāddur.

Şem‘î̀ (170b/6-12)

\section{Men ez nesìm-i sühan-çin çe taref ber-bendem}

Ben ġammāz nesīmden ne ümīd bag̉layam ya 'nī ne fầide ümīdlenem.

\footnotetext{
17 Örneklerde Sürûrî’nin Hâfız Dîvânı Şerhi için Nuruosmaniye 3963, Şem ‘î’ nin Hâfız Dîvânı Şerhi için Ayasofya 4062 numaralı nüshalardan faydalanılmıştır.

18 [Derkenar] Fārisīde "süḩan-çīn” "Arapça "žemmām” Türkçe "ḳovıcı” dimekdür. (Monlā Sürūrí)

19 [Derkenar] Fārisīde "sühan-çīn” 'Arapça "žemmām” Türkçe "ḳovıcı” dimekdür.
} 


\section{Çü serv-i rāst der in bāg nis̀t mahrem-i rāZ}

Tog̣nı serv gibi bu bāg̣da maḥrem-i rāz degüldür. Bu vech daḩı cā’izdür, çün rāst serv bu bāg̣da maḥrem-i rāz degüldür. Murād ṣuleḥā rāz-1 'işḳa maḥrem degül ḳande ḳaldı ki 'avām rāz-1 'işḳ̣a maḥrem ola dimekdür. Bu vech-i sāāi üzre vech-i evvele göre murād herkes maḥrem-i rāz olmag̉a lāyıḳ degüldür dimekdür.

2.Aşağıdaki beytin şerhinde Sürûrî' de yer alan "tâmât ve şath" ile ilgili derkenar notu Zâhid bin Muhammed'in metninde de derkenara alınmıştır. Sürûrî' nin şahit getirdiği gazel ise yoktur. Şem ‘î’nin "bahş" kelimesine dair derkenardaki gramer notu da bulunmamaktadir.

Zâhid bin Muhammed (218b/31-219a/4)

Țāmāt u şaṭh ${ }^{20}$ der reh-i āheng-i çeng nih

Tesbịh u taylesān be mey u meygüsār bah̆ş

Rüsūm ve elfāz-1 țariḳati ve kelimāt-1 ru ūnet ve da vā-yi ḥaḳiḳati çeng āhengi yolında ḳo tesbīh ve țaylesānı şerāb-ḩora bag̉ışla. Murād çengden şeyh ve murāḳıbdur, imdi ey

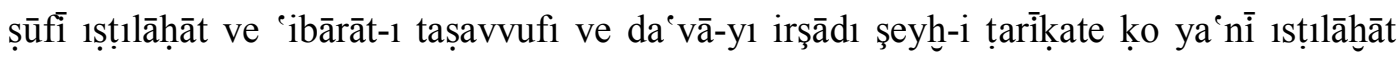
țariḳ-i irşādda olan şeyhündür ve tesbịh ve țaylesānı ve șūfiyāne vaże 1 ve șūreti melāmīye vir ya nī sen daḩı sūret ḳaydı ile muḳayyed olmayup 'āşıḳ-meşreb olanlardan ol. Mevlānā Şem ‘i dir, țāmāt ve şaṭ̣ı çeng ahengi yolına ḳo, tesbịh ve taylesānı şerāb ve şerāb-ḩora baġişla. Murād bunlaruy cemi 'sini terk idüp '1şḳa sa y eyle dimekdür. "Ṭāmāt" ḳavāeid ü rüsūm ve rueūnetle olan kelimātdur. "Şatḥ" kelimāt ve 1ṣ̣t1lāhật-1 șūfīyye.

Sürûrî (199b/7-16)

Țāmāt u şațh ${ }^{21}$ der reh-i āheng-i çeng nih

Rüsūm [ve] elfāẓ-I țariḳati ve ḥikemiyyāt-1 rue ūnet [ve] da vā-yi ḥakịịati çeng āhengi yolında ḳo.

Tesbịh u taylesān be mey u meygüsār bahş̧

20 [Derkenar] "Ṭāmāt u şaṭ”" neye denildügi mesțūrdan māe lum olur ehl-i fehm olana. (Monlā Sürūrī)

21 [Derkenar] "Ṭāmāt u şatḥ” neye denildügi mesțūrdan māe lum olur ehl-i fehm olana. 
Tesbīh ve țaylesānı şerāb-ḩora baġışla. Çengden murād şeyḩdür ki murāḳıbdur, imdi ey

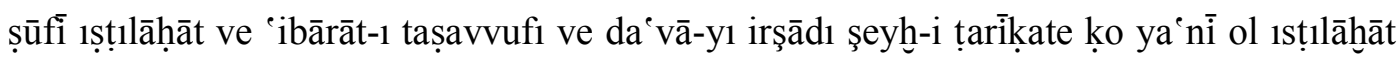
țarīḳ-i irşādda olan şeyhündür ve tesbịh ü țaylesānı ya nī ṣuffiyāne vaż 1 ve șūreti 'āşı̣̂-1 melāmetiyyeye vir ya'nī sen dahı șūret ḳaydı ile muḳayyed olmayup ‘āşı̣-meşreb olanlardan ol. Nitekim bir ${ }^{\mathrm{a}} \overline{\mathrm{s}} \mathrm{k}$. dimiş. Ġazel: ${ }^{22}(\ldots)$

Şem`î $(185 b / 23-186 a / 3)$

Ṭāmāt u şaṭ̣ der reh-i āheng-i çeng nih

Ṭāmāt ve şaṭ̣ı̣ çeng ahengi yolına ko.

\section{Tesbịḥ u taylesān be mey u meygüsār bahs și}

Tesbịh ve ṭaylesānı şerāb ve şerāb-ḩora bag̉ışla. Murād bunları terk idüp '1şḳa sa 'y eyle dimekdür. "Ṭāmāt" ḳavāeid ü rüsūm ve ru ūnetle olan kelimātdur. "Şatḥ" kelimāt ve 1ṣ̣t1lāhật-1 ṣūfīyye.

3.Aşağıdaki örnekte yine Sürûrî’nin derkenardaki notu ve şerhte geçen Arapça bir söz Zâhid bin Muhammed'in metninde bulunmaktadır. Şem'î’ye ait olduğunu belirttiği derkenar notu (meh-i çârdeh) ise Şem ‘î’nin bu makalede ele aldığımız nüshasında yoktur. Burada mürettibin yöntem ve tutumu hakkında onun esas aldığı nüsha olmaksızın tam bir hüküm vermenin mümkün olmadığı bir kez daha anlaşılmaktadır.

Zâhid bin Muhammed (220a/28-34)

\section{Çārdeh sāle bütī çāpük u şìīin dārem}

\section{Ki be cān ḩalka be-gūşest ${ }^{24}$ meh-i çārdeheş ${ }^{25}$}

On dört yaşında bir çāpük ve lezīiz maḥbūbum vardur ki cān ile ḳuldur aya on dört giceliḳ ay. Murād çārdeh-sāle maḥbūbdan Kur ān-1 'azīimdür ki on dört rivāyet ile yedi şeyhden mervīdür ve çāpük ü serie ü'l-ḳarārdur ki tilāvet-i tekrārsuz ḥıfz olınmaz ve lezīindür ki bir A rābī şehre gelüp K̦ureān istimāe idüp "Hāzāa kelāmu men fe'inne lehu

\footnotetext{
Buradaki gazel Zâhid bin Muhammed'in metninde yoktur.

[Derkenar] "Bahşs" emr-i hāżırırdur. (Bu not Zâhid bin Muhammed'in metninde yoktur.)

24 [Derkenar] Ḳul ḳulaġına diyar-1 'Acem’de ḩalḳa daḳarlarimiş. Lā-cerem ḩalḳa-be-gūş diyüp ḳul murād itdiler. (Monlā Sürūrī)

25 [Derkenar] "Meh-i çārdeh" on dört gicelik ay (Monlā Şemī)
} 
halāvetun keḥalāveti'l- 'aseli" ${ }^{26}$ diyü istifsār itmiş. Mevlānā Şem ‘ī dir, on dört yaşında mevzūn ü şīīin bir dilberüm vardur ki māh-1 çardeh cānile anun halḳa-be-gūşıdur. Bundan murād mürşīddür.

Sürûrî (201a/15-19)

\section{Çārdeh sāle bütī çāpük u şìīin dārem}

On dört yaşında bir çāpük ü lezīiz maḥbūbum vardur.

\section{Ki be cān halka be-gūşs ${ }^{27}$ est meh-i çārdeheş}

ki cān ile ḳuldur aya on dört gicelik ay. Çārdeh-sāle mạ̣būbdan murād Kurưān'dur ki on dört rivāyet ile yedi şeyhden rivāyet olınmışdur ve çāpük ü serī ü'l-ḳarārdur ki tilāvet-i tekrārsuz ḥıfẓolınmaz ve ležīzdür ki bir A rābī şehre gelüp Kur ān istimāe itmiş "Hāz̄ā kelāmu men fe'inne lehu halāvetun kehalāveti'l- aseli",28 diyü istifsār itmiş.

Şem‘î $(186 a / 8-10)$

\section{Çārdeh sāle bütī çābük u şīiñ dārem}

On dört yaşında mevzūn ü şīīin bir dilberüm vardur.

\section{Ki be cān halka be-gūşsest meh-i çārdeheş}

Ki māh-1 çārdeh cānile anuy ḩalḳa-be-gūşsıur. Bundan murād mürşīddür.

\section{SONUÇ}

Hakkında eserindeki küçük bilgiler dışında başka bir malumat bulunmayan Zâhid bin Muhammed Hâfız Dîvânı'na Sürûrî ve Şem 'î tarafından yapılmış olan şerhleri derleyen bir mürettiptir. İpekli gazilerden olan Zâhid bin Muhammed eserini hazırlarken bu iki eseri bir araya getirip tek bir metin hâlinde toplayarak Hâfı'’ okuyup anlamaya çalışanlara bir kolaylık sunmak istemiştir. Derlenen şerhlerin mukaddimelerinde olduğu gibi Zâhid Efendi'nin mukaddimesinde de "tercümânü'l-esrâr" ve "lisânü'l-gayb" lakaplarıyla anıldığı ve anlaşılması için tasavvufî remizlerin iyi bilinmesi veya bir bilen tarafından açıklanması gereği vurgulanan Hâfız'ın şiirlerinin anlaşılabilmesine katkıda

\footnotetext{
26 "Bu kimin sözüdür? Onda balın tatlılığg gibi bir tatlılık var."

27 [Derkenar] Kul ḳulaġına diyar-1 'Acem’de ḩalḳa daḳarlar imiş. Aya bināen halḳa-be-gūş diyü ḳul murād iderler.

28 "Bu kimin sözüdür? Onda balın tatlılığ 1 gibi bir tatlılık var."
} 
bulunmak -açıkça zikredilmemekle birlikte- bu eserin ortaya konmasındaki temel amaç gibi görünmektedir. Derlenen metnin sunduğu pratik fayda öncelikle okuyucunun iki ayrı eser arayışı içine girmeksizin tek bir metin içinde iki şerhi okuma imkânı bulabilmesidir. Kitabın modern zamanlardakiyle kıyaslanamayacak şekilde erişilmesi güç bir meta olması, kendi döneminin şartları içinde, onun eseriyle yapmaya çalıştığı işin ne denli önemli olduğunu göstermeye yeterlidir. Diğer yandan bu derleme tarz, teknik, yorum ve bakış açısı itibarıyla aynı geleneği takip eden metinler olduğunu bildiğimiz bu iki şerhin o dönemlerde de aynı çizgi üzerinde birbirini tamamlayan eserler olarak kabul gördüğünün ve birlikte mütalaa edilmesi gereğinin/ihtiyacının somut bir işareti sayılabilir. Bu eser kendi dönemi için olduğu gibi günümüz için de iki şerhteki açıklamaların kıyaslanmasına kolaylık sağlaması bakımından önem arzetmektedir. Örneğin Şem ‘î’nin beyit tercümelerinde Sürûrî’ye göre Arapça, Farsça kelimeleri daha çok kullanması ve kimi zaman beytin tercümesi dışında herhangi bir açıklamaya yer vermemesi, Sürûrî’nin tercümelerinde Farsça söz dizimini bozmadan çeviri yapması nedeniyle cümlelerinin devrik olması gibi iki şerhe dair karakteristik bazı özellikler bu derlemede doğrudan göze çarpmaktadır. Zâhid bin Muhammed bu anlamda her iki şerhin kıyaslama yapılarak okunması için ideal bir metin oluşturmuştur.

Şair, yazar, mimar, sanatkâr her kim olursa olsun eskilerin bir eser ortaya koyarak sağladıkları faydaya karşılık en önemli beklentilerinden biri dua beklentisidir. Bu eserin mürettibi de eserinin başında ve sonunda dua isteğini içtenlikle dile getirmiş, hayır dua ile anılmayı ve öldükten sonra ruhuna okunacak bir fatihayı nihai bir kazanç olarak göstermiştir.

Zâhid bin Muhammed'in eseri kendi içinde iki ayrı bölümden oluşur. İlk bölüm Hâfız'ın gazel, kıt'a ve rubâ'ilerinin Sürûrî ve Şem‘î tarafından yapılan şerhlerinin birlikte verildiği bölümdür. İkinci bölümde ise yalnızca Şem ‘̂̀’nin şerh ettiği bazı kaside, mesnevi, mugannî-nâme ve sâkî-nâme türünde şiirlerin şerhleri bulunur.

Mukaddimesinde kendisinin bir "mürettip" olduğunun altını çizen Zâhid bin Muhammed bu vasfinı eser boyunca koruyarak yorum ve açıklamalara herhangi bir müdahalede bulunmamış ve kendisinden bir ekleme yapmamıştır. Elbette iki ayrı eseri bir arada sunmaya çalışırken kaçınılmaz olarak kullanılan kalıp ibareler ve bağlayıcı ifadeler, beyit birimini esas almaktan kaynaklı olarak ifadelerde bazı düzenlemeler gibi söyleyişteki basit değişiklikler bunun dişında tutulmalıdır. Onun genel tasarrufu daha çok -eğer şerh ve açıklama uzunsa- özetleme ve kısaltma şeklindedir.

Zâhid bin Muhammed'in mürettip olarak yaptığı en önemli düzenleme misra birimi esasına dayalı bir şerh yöntemiyle kaleme alınan bu şerhleri beyit birimine dayalı bir biçime dönüştürerek bir araya getirmesidir. Mürettip eserleri mukaddimelerinden başlayarak birebir kopyalamıştır. Ancak şerhlerde, bilhassa uzun açıklamalar ve alıntılar içeren beyit şerhlerinde özetleme ve kısaltma yoluna başvurmuş; bazı kelime veya gramer bilgilerini yahut uzun şiir iktibaslarını almamıştır. Her iki şerhteki beyit tercümeleri ve beyitlerin delalet ettiği manalar mürettip için önceliklidir. Gramer açıklamaları, kelime anlamları, şahit getirilen şiir, söz veya açıklayıcı hikâyelerin alınması konusunda kesin ve belli bir yöntemden söz etmek zor olmakla birlikte anlaşıldığı kadarıyla mürettip bu bilgi ve iktibaslardan kendince önemli gördüğü veya konuyu fazla uzatmayıp eserin hacmini fazlaca artırmayacağını düşündüğü kısımları metnine dâhil etmiştir.

Zâhid bin Muhammed'in daha ziyade Sürûrî'nin şerhini zemin alarak bu eseri oluşturduğu anlaşılmaktadır. Mukaddimesindeki sözlerinde dahi bunun izleri görülür. Her iki şerh bağlamında düşünüldüğünde baskın metnin Sürûrî’nin metni olması bunu 
tabii kılmaktadır. Nitekim Şem ‘̂̂’nin de pek çok beyit şerhinde Sürûrî’nin çeviri ve yorumlarını takip ettiği, bir beytin başka bir veçhesinin bulunduğu durumlarda onu referans gösterdiği bilinmektedir.

Zâhid bin Muhammed'in metni şekil bakımından da şerh metinleriyle benzer özellikler taşır. İlk eser Sürûrî’nin şerhi olduğu için Şem ‘î’nin de onu model aldı̆̆ı söylenebilir. Her iki şerhte derkenar notları vardır. Zâhid bin Muhammed de her iki şerhte bulunan derkenar notlarından bazılarını kime ait olduğunu belirtmek kaydıyla derkenarlara yerleştirmiştir. Bu notlardan bazılarına metin içinde veya metin içinde bulunanlardan bir kısmına derkenarda yer verdiği de görülür. Burada görülen bazı farklılıkların nüsha ile ilgili olabileceği de göz önünde bulundurulmalıdır. Mürettibin kullandığı nüsha bilinmediği için bu konuda net bir hükme varmak mümkün değildir. Ancak Zâhid Efendi gazellerin vezinlerini Sürûrî'nin yaptığı şekilde gazelin başladığı yerde derkenara yazmıştır. Ayrıca kendisinin yanlış yazdığı veya yazıya geçirirken eklemeyi unuttuğu kısımları "sahh" kaydıyla derkenara notlamıştır.

Zâhid bin Muhammed'in bu eseri Sürûrî ve Şem 'î şerhlerini bir arada bulmaya ve birbiriyle kıyaslamaya imkân sağlaması bakımından önemli olduğu gibi iki farklı şerhi bir araya getiren bir derleme niteliğinde ünik olması bakımından da şerh literatüründe ayrı bir yere sahiptir. Hâfız'ın şiirlerine yapılan iki önemli şerhi bir araya getirmesi noktasından bakıldığında ise eserin Hâfız çalışmaları için özel bir yer taşıdığını söylemek gerekmektedir.

\section{KAYNAKÇA}

Arı, Osman Sacid. Mehmed Vehbi Konevi'nin Hafiz Divanı Şerhi'nde Tasavvufi Unsurlar. Yayınlanmamış Doktora Tezi. İstanbul Üniversitesi, 2016.

Ateş, Ahmet. İstanbul Kütüphanelerinde Farsça Manzum Eserler I. İstanbul: Milli Eğitim Basımevi, 1968.

Ayar, Mehmet Taha. "Hafız-1 Şirazi Divanı ve Osmanlı Şerhleri”. Misbah. 3-4 (1): 292295, 2013.

Ayar, Mehmet Taha. Hâfız-ı Şîrâzî̀nin Bazı Gazellerine Şerh Tekniği Açısından Sûdî ve Konevî̀nin Yaklaşım Tarzları. Yayınlanmamış Yüksek Lisans Tezi. İstanbul Üniversitesi, 2007.

Çelik, Ahmet Faruk. Sürûrî’nin Hâfız Dîvânı Şerhi'nin Incelenmesi. Yayınlanmamış Yüksek Lisans Tezi. Konya: Selçuk Üniversitesi, 1996.

Gölpınarlı, Abdülbâkî. Hâfız Dîvânı. İstanbul: MEB, 1992.

Hürremşahî, Bahâüddin. Hâfiznâme I. Tahran, hş.1280.

Kiel, Machiel. “İpek”. TDV İslâm Ansiklopedisi. 22: 366-368, İstanbul, 2000.

Oğuz, Meral Ortaç. "Sürûrî'nin Şerh-i Dîvân-1 Hâfız'1". Yayımlanmamış Yüksek Lisans Tezi. İzmir: Ege Üniversitesi, 1998.

Safâ, Zebihullah. Iran Edebiyatı Tarihi II. çev. Hasan Almaz. Ankara: Nüsha Yayınları, 2005.

Serezli, Esad. "Nur-u-Osmaniye Kütüphanesi Bibliotheque de la Mosquee de Nour-ouOsmaniye".Türkiye Turing ve Otomobil Kurumu Belleteni. 19-20. Mayıs 1948.

Sürûrî. Şerh-i Dîvân-ı Hâfız.Nuruosmaniye 3963. 
Şem ‘î. Şerh-i Dîvân-ı Hâfız. Ayasofya 4062.

Turan, Mustafa. Zâhid bin Muhammed'in Kitâb-ı Şem ‘̂̀ ve Sürûrî 'Alâ Dîvân-ı Hâfız Adlı Eseri (vr.201b-225a Inceleme - Metin). Yayınlanmamış Yüksek Lisans Tezi. Mardin Artuklu Üniversitesi, 2019.

Yazar, Sadık. Anadolu Sahası Klasik Türk Edebiyatında Tercüme ve Şerh Geleneği. Yayınlanmamış Doktora Tezi. İstanbul Üniversitesi, 2011.

Yazıcı, Tahsin. "Hâfız-1 Şirâzî". TDV İslam Ansiklopedisi. 15: 103-106. İstanbul, 1997.

Zâhid bin Muhammed. Kitâb-ı Şem‘î ve Sürûrî 'Alâ Dîvân-ı Hâfız. Nuruosmaniye 3962. 
EK

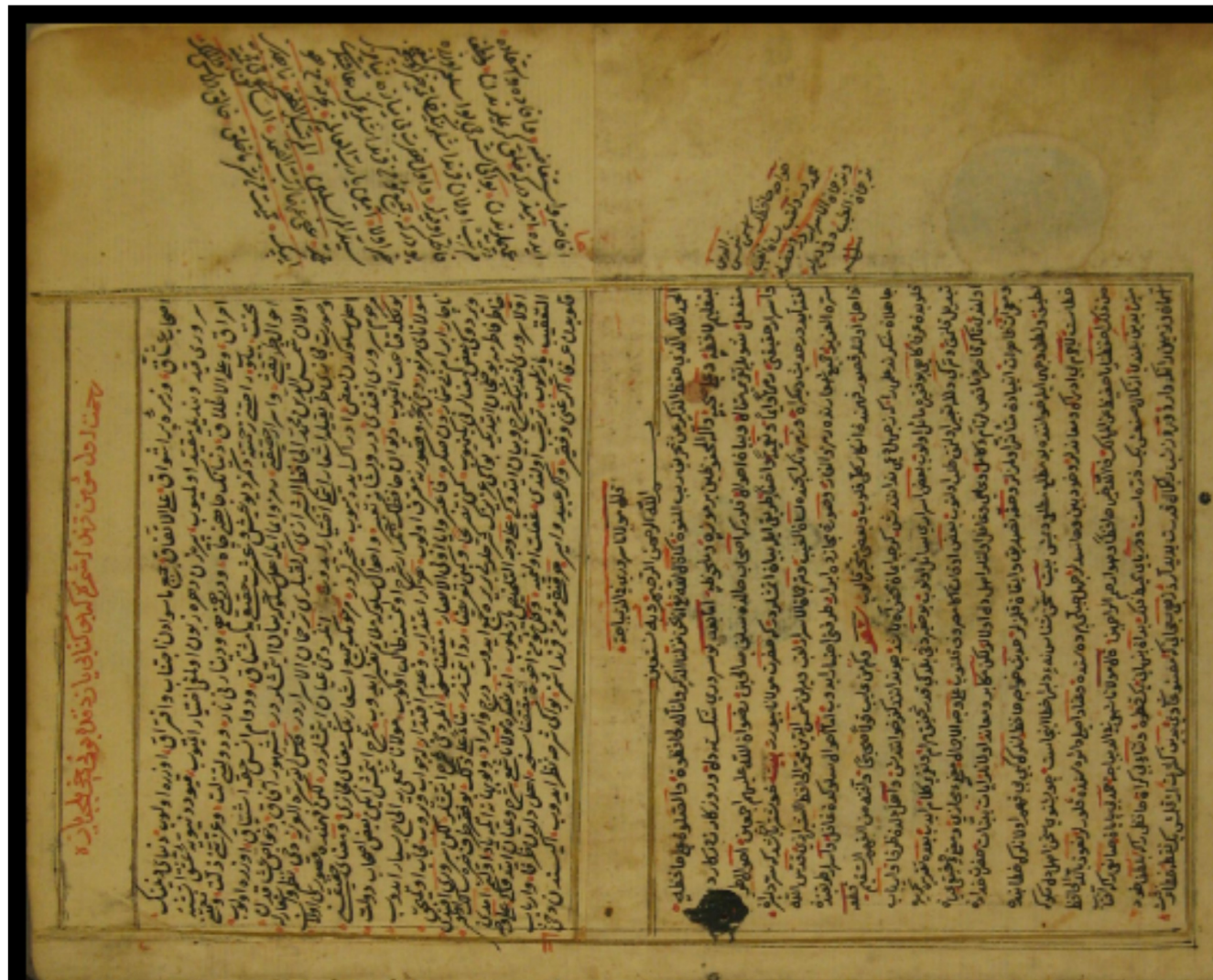

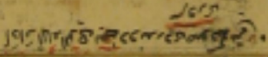

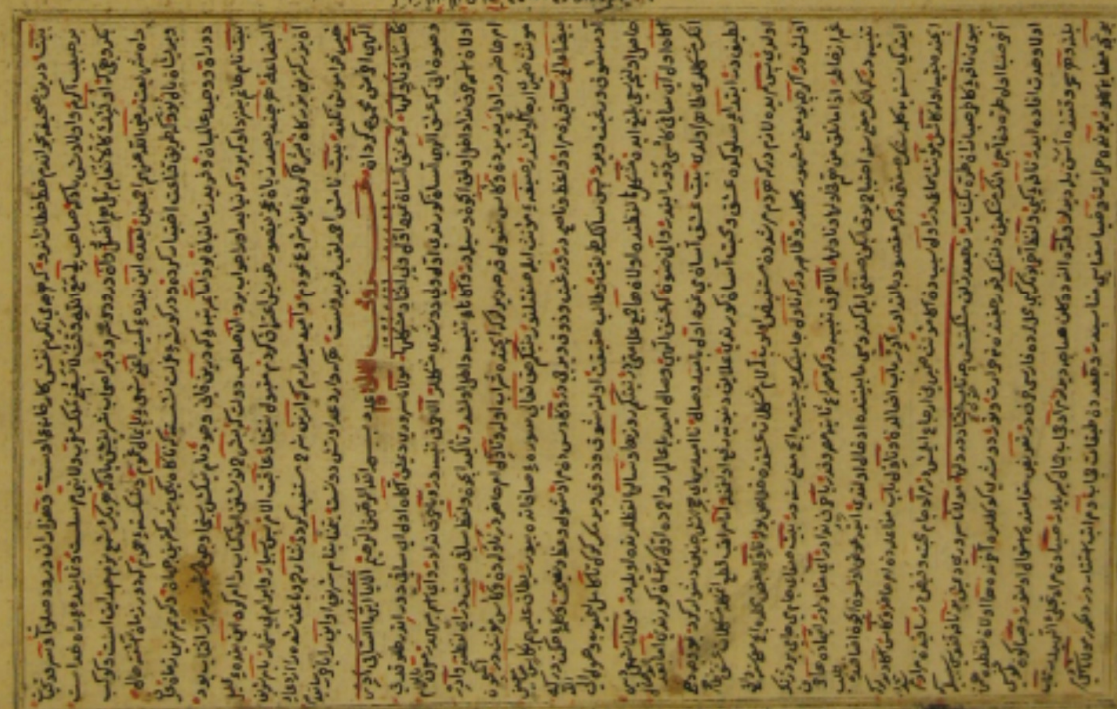

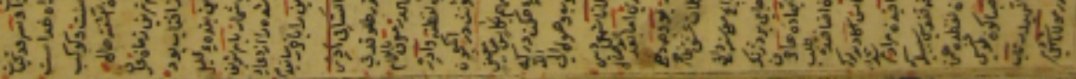

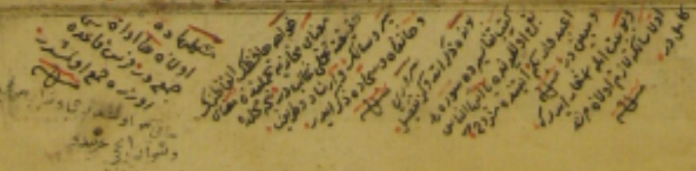




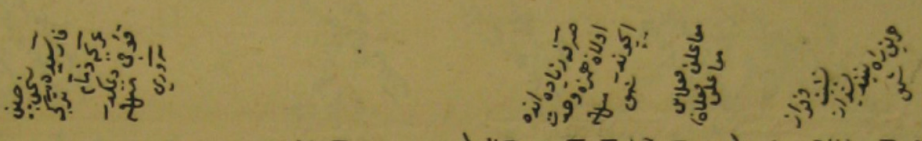

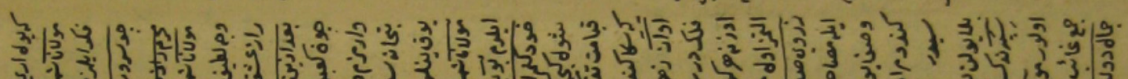
等 -3.

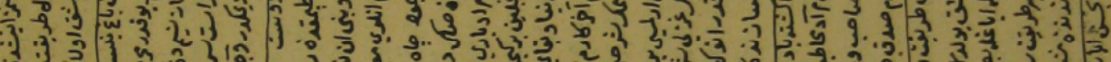
- 30 .

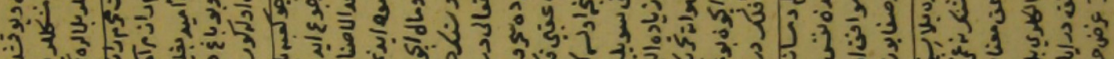

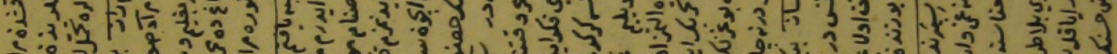
交.

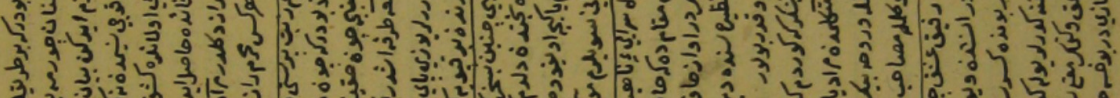
3.

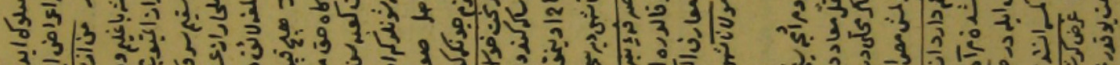
(3) र. - 2. 3. ख़ी

$1 \frac{1}{2}$ है $3^{3}$ 3. तो

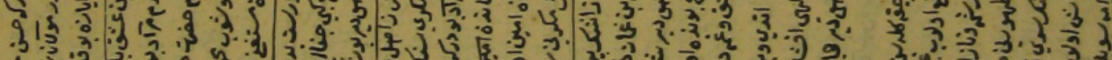
1) 3.

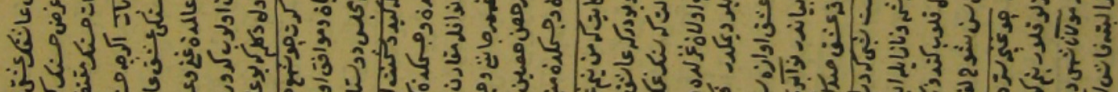
3. 3.

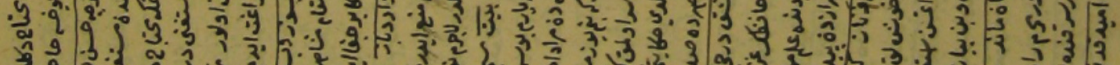

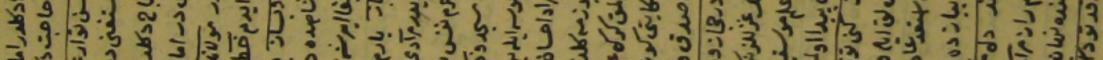
等 13 (-) क. की

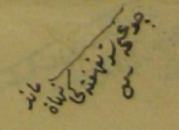




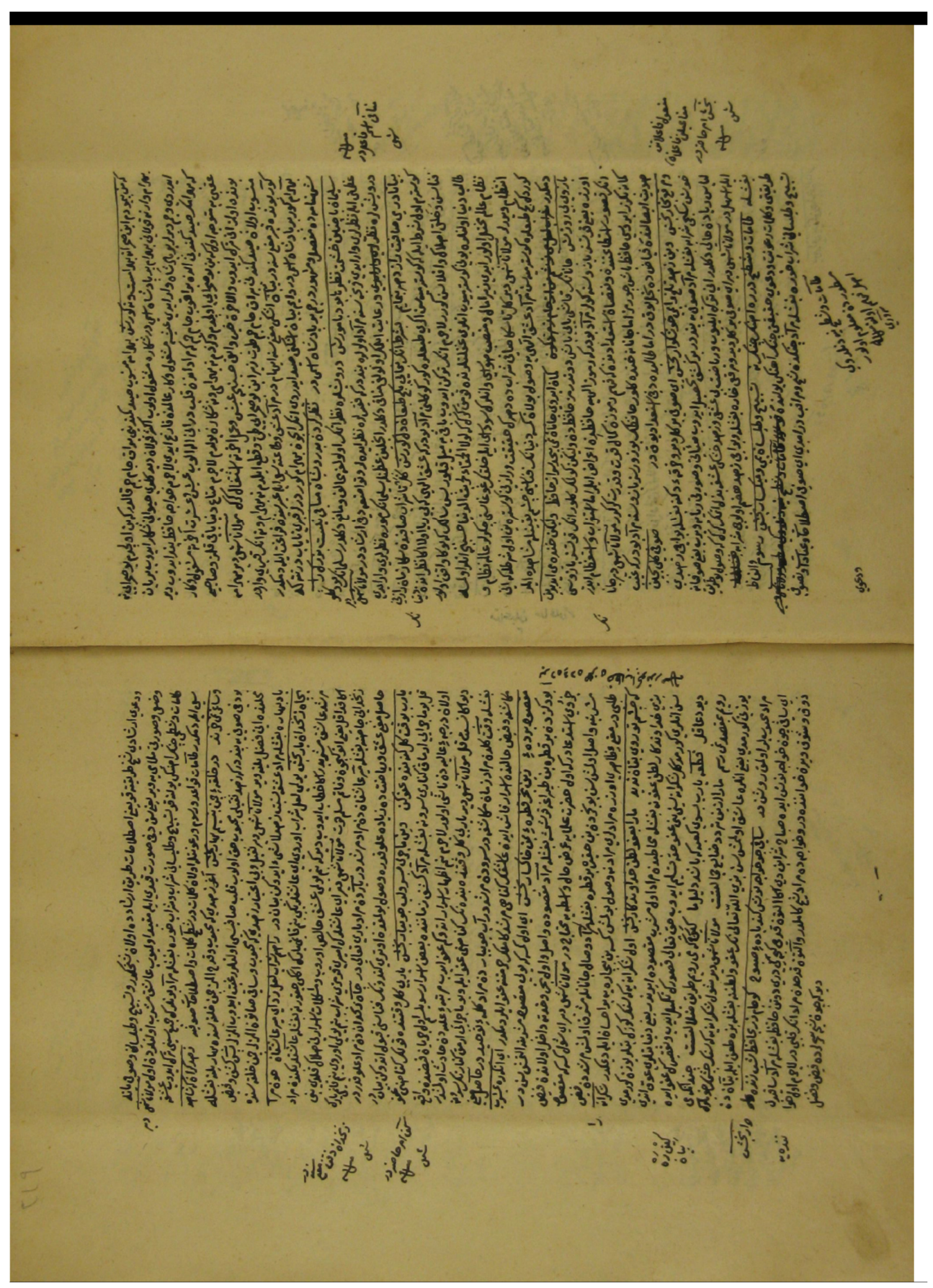

